\title{
Ethnobotany as A Science of Preserving Traditional Knowledge: A Case Study of Herbal Uses of Plants in Trans-Himalaya (Ladakh), India
}

Shiekh Marifatul Haq

University of Kashmir

Eduardo Soares Calixto

Universidade de Sao Paulo

Zubair A. Malik

Govt. HSS Harduturoo Anantnag

Ripu M. Kunwar ( $\nabla$ ripukunwar@gmail.com )

Ethnobotanical Society of Nepal https://orcid.org/0000-0002-9303-0932

\section{Research}

Keywords: Ethnobotanical usage, medicinal plants, hotspot biodiversity, Amchis, Chord diagram

Posted Date: April 2nd, 2020

DOI: https://doi.org/10.21203/rs.3.rs-20416/v1

License: (c) (i) This work is licensed under a Creative Commons Attribution 4.0 International License. Read Full License 


\section{Abstract}

Background - The sixth anthropocene mass extinction in the last 540 million years indicates that human activities including illegal trade is the fundamental threat to the endangered species, their habitats and to the global biodiversity as well. In this context, it is paramount keeping in view the role of hotspot regions in the conservation of biodiversity and their varied potential of ethnobotanical services. The present study quantified the traditional ethnobotanical usage and people's choices of plants and evaluated the composition, distribution, trade and conservation of plants in Ladakh region, India.

Methods - During 2018-2019, ethnobotanical documentation of the plants growing in Ladakh (a part of trans-Himalaya), India, was carried out to collect information regarding different usages of plant species growing in the region through open and close-ended questionnaire surveys and interviews. Multivariate ecological community analysis was used to find the relationship between ethnobotanical usage and plant species.

Results - Floristically, a total of 103 species belonging to 80 genera and 38 families were reported to be used as medicine, food, fodder, fuelwood, fragrance, dye, flavor and oil. Asteraceae was the largest family with $20 \%$ species, followed by Ranunculaceae ( $10 \%$ species) and Fabaceae ( $7 \%$ species). Three plant usage clusters were determined at a vertical distance value of 0.4 where the clusters are distinctly separated. Preference analysis showed the highest priority of local people for medicinal use of plants followed by fodder and fuelwood. The most frequently used plant parts were leaves followed by roots and flowers. Local Amchis and elderly people had great familiarity with medicinal plants and their ethnic usage. The plant species harvested were sought for self-consumption (65\%) and for commercial purposes (35\%).

Conclusions - The present study provides unique information regarding the ethnobotanical knowledge in Ladakh region and baseline data for future researchers, policymakers, public, land managers, and the other stakeholders to develop scientifically-informed strategies for conservation of natural resources and sustainable use of plant diversity in hotspot regions like trans-Himalayas and other similar biodiversityrich sites.

\section{Background}

From ancient times, through "trial and error" and experience, mankind across the world has learned and practiced the usage of medicinal plants growing in their surroundings for treating different ailments [12]. Ethno-medical practices are considered as the mother of all the traditional systems of medicines like Unani, Siddha, Ayurveda, Sowa-Rigpa or Amchi and even to modern allopathic system [3]. It has been found that more than $80 \%$ of people living in the third world countries are dependent on the plant-based medicines for their traditional medicines [4] and people from Africa, Asia, Central and South America are mainly dependent on these plant-based medicines for treating various diseases [5]. Most of the medicinal preparations used in the modern allopathic system derive their origin from plants and are mainly 
encouraged because of their use in traditional folklore for treating various ailments [6-7]. Furthermore, modern pharmacopeia contains about $25 \%$ drug preparation derived from plants and are mainly synthetic analogs prepared on prototype compounds having plant origin. It has been projected that the trade of these medicinal and aromatic plants in the healthcare industry costs about $\$ 60$ billion annually [8] and may reach $\$ 5$ trillion by 2050 [9] due to increasing recognition of plant-derived medicines [10]. This popularity of these plant-based medicines is because of their less side-effects than the allopathic medicines [11].

Many of the modern medicines used today find their origin in folk-use and indigenous cultures [12-13]. Hence the source of this traditional information about these medicinal plants is possessed by these indigenous cultures and this information survives due to its transfer through generations [1]. However, due to cultural transformation land use change and deforestation, the facility of modern health care and rapid urban development has changed the distribution of these indigenous cultures disturbing the transformation of traditional knowledge about medicinal plants [14]. Ethnobotanical analyses have developed a key association among traditional knowledge, indigenous people and use of plants [15-17]. The ethnic tribal communities have adopted local plants as the traditional means of healing systems and are broadly used by all sections of the community, whether directly as folk remedies or the medicaments of the different indigenous systems as well as in modern medicine system [18-19]. The traditional information occupies a vital position at the global level right from the primitive past to the present [20]. Indigenous communities have been utilizing plant sources for a variety of purposes over many generations [21]. Ethnobotanical research explores avenues how the medicinal plants are used in culture, subsistence, primary health care [22], drug discovery and conservation [18, 19]. During the last century, the field of ethnobotany has progressed significantly and now this field is shifting from simple documentation to a more practical one, which gives importance to the conservation and sustainable management of medicinal flora [23].

The Indian Himalayan Region (IHR), occupying about $18 \%$ area of India, is considered as one of the mega hotspots of the world [24]. It has been reported that about 1289 plants belonging to 960 taxa and 560 genera are under medicinal trade in India, various parts of which are sold and used across India. The utilization of these medicinal plants in the Indian System of Medicines (ISM) includes 328 in Unani, 688 in Ayurveda, 146 in Homeopathy, 501 in Sidda, and 197 in Tibetan [25]. Ladakh region, part of transHimalaya, is a hub of medicinal, aromatic and other economically important plants [26]. However, the ethnobotanical studies of this region are meager. Also, the floristic diversity of the region is under continuous pressure by local inhabitants, tourists, overgrazing and various developmental projects. Keeping in view the role of the region in the conservation of biodiversity and its varied potential of ethnobotanical services into account, the present study was conducted with the specific aim of quantifying the traditional ethnobotanical usage of plants in Ladakh region. The results of the present study will provide baseline data for future researchers, policymakers, common public, land managers, and the other stakeholders to develop scientifically informed strategies for conservation of natural resources and sustainable use of plant diversity in this trans-Himalayan region. Ethnobotanical field survey may be 
an alternative to document and conserve this imperative knowledge before it disappears. The indigenous valuable ancestral information on medicinal plants may fill the associated knowledge gap for the future.

\section{Methods And Material}

\section{Study area}

Ladakh (Trans-Himalayan region) of Indian Himalayan Region (IHR) is known for its extremely cold climate with rocky, uneven terrains, alpine medicinal plant wealth and wild fauna. The geo-coordinates of this region are in between $34^{\circ} 12^{\prime} 34.25^{\prime \prime} \mathrm{N}$ and $77^{\circ} 36^{\prime} 54.40^{\prime \prime} \mathrm{E}$ (Fig. 1) falling between the states of Himachal Pradesh to the south and Jammu and Kashmir to the west. The region is also bordered by countries like Tibet to the east, Baltistan to the west (Baltistan is an administrative territory of Pakistan) and the southwest corner of Xinjiang territory of China. The study area extends from the Siachen Glacier (Karakoram Range to the north) to the south of Great Himalayas [27].

Ladakh has two large district towns, Leh and Kargil, with eight (Leh, Changthang, Nubra, Drass, Suru, Zanskar, Spiti and Lahaul) major valleys with their unique features and characteristics. Most populated areas are the river valleys of district Leh which are Nubra, Shyok and Indus; but Changpa nomads are also observed to be supported by the mountain slopes of this hinterland.

\section{Survey and Data Collection}

The reconnaissance field surveys were done in Ladakh area for the understanding of the accessibility, nature of terrain and distribution of the flora. A forest working plan was consulted for authenticating geographical location, administrative jurisdiction and wild flora. The representative sites $(n=54)$ were visited through five trips between 2018 and 2019. The documentation of traditional knowledge and ethnobotanical notes of plant resources was based on interviews using open and closed ended questionnaires and discussions. The interviews were mainly based on intersperse fact-based questions [28-29]. Verbal or prior informed consent was sought and obtained from the concern panchayat head as well as the concerned individual informants by briefing clearly about the objectives of the study. Different knowledgeable persons of the area were interviewed, such as Amchis (traditional doctors), hunters, herders and other common denizens like shopkeepers, farmers, daily wage laborer, hotel owners, museum owners, housewives and Govt. employees. Among these, Amchis, herders/shepherds, hunters and those residing in rural and/or far-flung areas are much more informative as compared to others as they are directly dependent on plant products for their livelihoods.

Informants were asked about the uses of plants, such as medicinal, food, fodder, fuelwood, fragrance, dye, decoration, flavor and oil. Field-based observations and both formal and informal discussions were carried out for additional information. The respondents were further asked about their species preference if they utilized a species for self-consumption or trade for earning purposes. A total of 269 informants (208 males and 61 female) were involved in this study, representing over $10 \%$ of total population of site. There were only $23 \%$ female participants as compared to male $77 \%$. The less female participants could 
be a reason that women remain indoor and they have less exposure of wild forests and distant sites. About $88 \%$ of the informants were above 45 years old while $65 \%$ were illiterate.

From each study site, one knowledgeable respondent was requested to accompany us to collect plant specimens for the authentication and herbarium preparation. Each of the collected voucher specimens was coded. Pictorial field guide Murthi [30] and Chaurasia et al. [31] was used for identification. The collected specimens were further checked for proper identification with the help of taxonomists at Centre of Biodiversity and Taxonomy, University of Kashmir, Srinagar (J\&K) and standard literature [32-33]. Later the doubtful and unidentified plants were identified and verified from the authenticated herbarium specimens at Centre of Biodiversity and Taxonomy, University of Kashmir (KASH herbarium). The voucher specimens were deposited at KASH herbarium.

\section{Data analysis}

Vegetation data were statistically analyzed to find out the relationship between ethnobotanical usage and plant species. The presence/absence data were subjected to the classification of different ethnobotanical similarities and differences among the different plant usage via PAST software. We also used a ChiSquare "Goodness of Fit" test to verify if there was a difference in the usage of plants. Sorensen's (BrayCurtis) distance was used to identify significant differences among the different plant and ethnobotanical usage similarities [34-35]. Principal Component Analysis was used to finding hypothetical variables (components) that account for as much of the variance in the multidimensional data as possible [36-37] using PAST software. The contribution of different plant part usage was displayed in chord diagrams using circlize package [38] in R software 3.6.1 [39].

\section{Results}

\section{Vegetation Composition and Distribution of Plant Species}

The present study recorded a total of 103 species belonging to 80 genera and 38 families (Table 1). The species dispersion across 38 families is unequal with six families contributed half of the species, while 32 families represented the remaining half of the species (Fig. 2). Out of the 32 families, 18 were monotypic (Fig.2; Table 1). Asteraceae is the largest family with $20 \%$ species, followed by Ranunculaceae (10\% species), Fabaceae (7\% species), Apiaceae and Lamiaceae (5\% species each). The remaining species contributed by Polygonaceae, Amaryllidaceae, Berberidaceae, Boraginaceae, Gentianaceae, Poaceae, Rosaceae, Orchidaceae, Plantaginaceae and Urticaceae (Table 1).

\section{Plant Usage Classification}

Three plant usage clusters were determined at a vertical maximum similarity of about 0.2 (Fig. 3). The three distinctly separate clusters were: (1) food and medicinal plants; (2) dye and flavor; and (3) fragrance, oil, fuelwood and fodder. Clusters 2 and 3 showed almost $50 \%$ similarity in plant usage. 
Moreover, the similarity in plant usage between fuelwood and fodder, and fragrance and oil as well, showed almost $100 \%$ of similarity (Fig. 3 ).

\section{Plant parts used}

Different parts of plants were documented for ethnobotanical usage (Fig.4) with a significant difference between their usage $\left(\chi^{2}=100.12, d f=9, p<0.001\right)$. The most frequently used plant parts were leaves $(27 \%)$ followed by roots $(21 \%)$, flowers $(15 \%)$, stem $(10 \%)$, fruits and whole plant ( $9 \%$ each), bulbs (3\%), bark and seed and young twigs ( $2 \%$ each) (Fig.4).

\section{Preference analysis}

The results of preference analysis showed a significant difference in plant usage $\left(\chi^{2}=408.56, d f=7\right.$, $p<0.001)$. The highest priority of local people was for medicinal use of plant species ( $70 \%$ responses) followed by fodder ( $9 \%$ ) and fuelwood ( $8 \%)$, food (6\%), fragrance (4\%) and dye, flavor and oil ( $1 \%$ each) (Fig.5). This fact is also supported by principal components analysis (PCA), which showed distinct usage segregation based on variations in the preference levels (Fig. 6). PCA correlated the most important components with other underlying variables.

\section{Important medicinal plant species and their local usage}

The local Amchis and elderly people are well aware of the medicinal plants and their ethnic usage. All the medicinal species with their respective usage are given in Table 1. Each medicinal species found in the region is worth mentioning, but a few of them got much significance in the traditional 'Sowa-Rigpa'health care system. These include Bona karpo (Aconitum heterophyllum), Bona nagpo (Aconitum violaceum), Chu-Rtsa (Rheum webbianum), Lachhu (Rheum spiciforme), Spang-rtsa (Saussurea bracteata), Manu/push karmool (Inula racemosa), Kuth (Saussurea lappa), Khizer/Kiraring (Berberis ulicina), AmboLakpa (Dactylorhiza hatagirea), Bri-mok (Arnebia euchroma) and Nia-Mentok (Aster flaccidus). Among other species, Arnebia guttata, Bergenia stracheyei, Corydalis govaniana, Colchicum luteum, Delphinium cashmerianum, Ephedra gerardiana, Ferula jaescheana, Gentiana algida, Hippophae rhamnoides, Lagoti scashmeriana, Meconopsis aculeate, Picrorhiza kurrooa, Jurinea dolomiaea, Rhodoendron anthopogon and Vincetaxicum caneces are also of great importance in the traditional health care.

\section{Plant trade status}

During interviews, we came to know that the medicinal plant species are harvested by the local people both for self-consumption (65\%) and for commercial purposes (35\%). The local people particularly herders and Amchis collects wild medicinal plants at the household level for both folklore use and trade every year.

\section{Discussion}


High-altitude cold desert Ladakh region of the trans-Himalaya is characterized by the arid and cold climate that remained isolated and poorly accessible; hence the region appears to be less investigated in terms of ethno-ecological research. The availability of medicinal, aromatic and other economically important plants, and the cultural, physical and geographical isolation has thus resulted in the development of a unique traditional plant usage system in the region $[26,40]$. The present ethnobotanical study reported 103 plant species belonging to 80 genera and 38 families. The species richness recorded is similar to those reported by several ethnobotanical workers from different regions of the Himalaya. For instance, Khan et al. [28] reported a total of 101 species from Naran Valley, Western Himalaya, Pakistan, Awan et al. [41] reported traditional knowledge of 102 economically important plants from Mansehra District, Pakistan, and Kayani et al. [21] reported studied ethnobotany of 125 medicinal plants from Alpine and Sub-alpine regions of Pakistan. Similar results were reported by other studies $[28,42,43]$.

In terms of floristic distribution patterns, our observations can be compared with those from mountain regions in the Himalayas, where floristic groups such as Asteraceae, Ranunculaceae, Fabaceae, Apiaceae and Lamiaceae were the most dominant representative families. Many researchers have reported Asteraceae as the dominant family from various ethnobotanical studies $[26,40,42,44]$. Due to wide ecological amplitude, the plant species of family Asteraceae adapt easily and get distributed in arid dry habitats [45, 46] In addition, Kayani et al. [21] reported Ranunculaceae as the dominant family from Alpine and Sub-alpine regions of Pakistan, and Abbas et al. [29] reported Fabaceae as the leading family from the Baltistan region of Karakorum Range-Pakistan, which are in line with our results. The floristic analyses revealed the unequal distribution of species across families and 18 families were monotypic. These values alike to the previously reported values from a different region of the Himalaya $[46,47,48]$.

Local people showed the highest priority for the medicinal use followed by fodder (Figs. 5 and 6 ). Earlier reports also have similar account of the highest priority of plants for the medicinal use $[28,49,50,51,52]$. Sharma et al. [53] studied ethnobotanical uses of floristic diversity in Himachal Pradesh and reported that $82 \%$ of plant species had medicinal importance. Ahmad et al. [54] reported the utilization of most of the plant species for medicinal and fodder purposes in Pakistan Himalaya. The highest proportion of plant species were utilized for medicinal purposes followed by fodder in Azad Jammu and Kashmir [55] and Gujjar, Western Himalaya [56]. Due to higher dependence on medicinal plants for treating various ailments and demand by the pharmaceutical industry, the locals especially Amchis, shepherds and herbal drug dealers prefer the medicinal usage of local flora. Major portion of the harvested medicinal plants $(65 \%)$ was used for self-consumption while the rest $(35 \%)$ was sold for commercial purposes. The area has a considerable potential for livestock farming due to presence of sufficient fodder. Animal husbandry, summer grazing and medicinal plant collection and trade are the major livelihood portfolios in arid and alpine regions of the Himalaya [57].

In the present study different parts of ethnomedicinal plants were used for treating various ailments (Fig. 4). The leaves were used more frequently (27\%) as compared to other parts like roots (21\%), flowers $(15 \%)$, stem (10\%), fruits and whole plants (9\% each) etc. Similar results were reported by Keter and Mutiso [58] from Kenya; Malik et al. [59]; Rathore et al. [60]; Singh et al., [61] from Indian Western 
Himalaya, Akhtar et al. [62] from Pakistan, and Kunwar et al. from Nepal [63]. Our results are also supported by other ethnobotanical studies conducted in elsewhere and different regions of the Himalaya $[26,29,40,53-56,64]$. Besides leaves, roots are also the most preferred parts used by the local inhabitants because they contain a higher concentration of bioactive compounds than other parts [65]. Hence the local Amchis prefer to use the roots of the plants for medicinal usage.

Many of the medicinal plants are facing threat because of the collection of their underground parts on a large scale, such as Aconitum heterophyllum, Aconitum violaceum, Corydalis govaniana, Dactylorhiza hatagirea, Inula racemosa, Bergenia stracheyi, Delphinium cashmerianum, Saussurea bracteata and Picrorhiza kurrooa, among others. These species have become endangered throughout the transHimalayan region due to over-collection underground parts for these plants for trade purposes $[26,59,66$, 67]. Previously, local Amchis used these plant resources for their consumption, but now there is a large collection promoted by pharmaceutical companies [68]. All the major medical traditions of south Asia have been using Himalayan plants in their formulations, but the indigenous Sowa-Rigpa system of Ladakh and other Himalayan regions is especially based on the skillful use of these medicinal plants. Till the 1980s the trans-Himalayan (Ladakh) plants were only used by the local Amchis and people for their domestic needs and treating patients [68]. Plants have been the historical backbone of traditional healthcare practices across major societies and still $75-80 \%$ of the world population uses medicinal plants today for primary health care needs [69]. In India $90 \%$ of medicinal plants used by local tribal communities are sourced from the wild [70]. The high demand for herbal drugs has led to the uncontrolled collection of medicinal plants from nature, leading to depletion of biodiversity. For instance, the trans-Himalayas (Ladakh region) has seen depletion of many medicinal herbs. Similarly, numerous other threatened medicinal plants are overexploited for their therapeutic potential [68]. The recent climate changes and habitat loss are another matter of great concern for the survival of these high-altitude plant species $[71,72]$. The habitats of most of these species fall within the extensively grazed alpine meadows. Overgrazing has destroyed plant species, as green parts are being removed and damaged due to trampling, mechanical injuries and land erosion [73-75]. With the expansion of roads and increased population have exposed this herbal wealth and brought new commercial interest. The transformation from the need to greed for trans-Himalayan plant species has been increased tremendously. It is observed during our surveys that these plant species are under harvesting pressure and need urgent action for conservation. While we may welcome the growth of traditional medical systems, but it is very important to balance and reconcile these trends for sustainable development.

\section{Conclusions}

This study provides new contributions to floristic composition and plant use by locals in the transHimalayan mountainous regions. These regions represent a hotspot of biodiversity and therefore need to be preserved due to their high potential for endemic biodiversity and degradation. Studying the floristic composition and use of these plants by the local human populations is fundamental to understand how the plant communities in these regions are being affected by human actions. We have shown that plants are used for different purposes, including treating diseases. Considering that the low social conditions of 
these populations and the difficulty of reaching centers with better health conditions, the use of these vegetables as local medicine becomes increasingly essential for the populations of these regions. On the other hand, improper and negligent use causes the plant community to be drastically affected, changing its composition over the years. Thus, we highlight the importance of our study as a tool that will help in understanding the structuring of plant communities in these regions, and how mitigation and conservation measures can be taken for the recovery and preservation of the Himalayan plant communities.

\section{Abbreviations}

$\mathrm{IHR}=$ Indian Himalayan Region; $\mathrm{SMH}=$ Shiekh Marifatul Haq; $\mathrm{KASH}=$ Acronym Herbaium of Kashmir University; $\mathrm{CAMP}=$ Conservation Assessment and Management Plan.

\section{Declarations}

\section{Ethics approval and consent to participate}

Ethics approval is not applicable while all the participants provided prior informed consent before the interviews.

\section{Consent for publication}

Not applicable

\section{Competing interests}

The authors declare that they have no competing interests.

\section{Availability of data and materials}

Data are available in the article. Other associated data are available on request.

\section{Funding}

This research did not receive any specific grant from funding agencies in the public, commercial, or notfor-profit sectors.

\section{Authors' contribution}

SMH carried out the field study and analyzed the data. SMH and ESC wrote the manuscript. ZAM contributed in specimen identification. ZAM and RMK thoroughly revised the manuscript. All authors read and approved the final manuscript.

\section{Acknowledgements}


The authors are thankful to the Head, Department of Botany University of Kashmir for providing working facilities. Thanks are due to the local people of Ladakh for sharing the ethnobotanical information and cooperating during the surveys and interviews.

\section{References}

1. Gurib-Fakim A. Medicinal plants: traditions of yesterday and drugs of tomorrow. Mol Aspect Med. 2006; 27(1):1-93.

2. Karunamoorthi K, Jegajeevanram K, Vijayalakshmi J, Mengistie E. Traditional medicinal plants: a source of phototherapeutic modality in resource-constrained health care settings. Evid Based Complement Alternat Med. 2013;18(1): 67-74.

3. Vogel VJ. American Indian Medicine (Vol. 95). University of Oklahoma Press. 2013.

4. World Health Organization. Traditional Medicine, 2003, Fact sheet No 134. http://www.who.int/mediacentre/factsheets/fs134/en/ Newman, D.J., Cragg, G.M. Natural products as sources of new drugs over the 30 years from 1981 to 2010. J Nat Prod. 2012; 75(3):311335.

5. Allkin B. Useful Plants-Medicines: At Least 28,187 Plant Species are Currently Recorded as Being of Medicinal Use. 2017.

6. Newman DJ, Cragg GM. Natural products as sources of new drugs over the 30 years from 1981 to 2010. J Nat Prod. 2012; 75(3):311-335.

7. Aziz MA, Khan AH, Adnan M, Izatullah I. Traditional uses of medicinal plants reported by the indigenous communities and local herbal practitioners of Bajaur Agency, Federally Administrated Tribal Areas, Pakistan. J Ethnopharmacol 2017; 198: 268-281.

8. Hamilton A. Plant Conservation: An Ecosystem Approach. Earthscan, London, UK. 2006.

9. Shinwari ZK, Gilani SS. Sustainable harvest of medicinal plants at Bulashbar Nullah, Astore Northern Pakistan. J Ethnopharmacol 2003; 84:289-298.

10. Al-Quran S, Taxonomical and pharmacological survey of therapeutic plants in Jordan. J Nat Prod. 2008; 1:10-26.

11. Miliauskas G, Venskutonis PR, Van Beek TA. Screening of radical scavenging activity of some medicinal and aromatic plant extracts. Food Chemistry. 2004;85(2): 231-237.

12. Lewis WH, Elvin-Lewis MP. Medicinal plants as sources of new therapeutics. Ann Missouri Bot Gard. 1995;16-24.

13. Qureshi RA, Ghufran MA, Gilani SA, Yousaf Z, Abbas G, Batool A. Indigenous medicinal plants used by local women in southern Himalayan regions of Pakistan. Pak J Bot. 2009; 41(1): 19-25.

14. Posey DA, Dutfield G. Beyond intellectual property: toward traditional resource rights for indigenous peoples and local communities. IDRC. 1996.

15. Turner WR, Tjørve E. Scale dependence in species are a relationship. Ecography. 2005; 28(6):721730. 
16. Pieroni A, Nebel S, Quave C, Münz H, Heinrich M. Ethnopharmacology of liakra: traditional weedy vegetables of the Arbëreshë of the Vulture are a in southern Italy. J Ethnopharmacol. 2002; 81: 165185.

17. Verpoorte R, Choi YH, Kim HK. Ethnopharmacology and systems biology: a perfect holistic match. J Ethnopharmacol. 2005;100(1): 53-56.

18. Singh KN, Lal B. Ethnomedicines used against four common ailments by the tribal communities of Lahaul-Spiti in western Himalaya. J Ethnopharmacol. 2008; 115(1):147-159.

19. Mahmood A, Mahmood A, Shaheen H, Qureshi RA, Sangi Y, Gilani SA. Ethno medicinal survey of plants from district Bhimber Azad Jammu and Kashmir, Pakistan. J Med Plant Res. 2011; 5(11): 2348-2360.

20. Ghorbani A. Studies on pharmaceutical ethnobotany in the region of Turkmen Sahra, north of Iran (Part 1): General results. J Ethnopharmacol. 2005; 102:58-68.

21. Kayani S, Ahmad M, Sultana S, Shinwari ZK, Zafar M, Yaseen G, Hussain M, Bibi T. Ethnobotany of medicinal plants among the communities of Alpine and Sub-alpine regions of Pakistan. $J$ Ethnopharmacol. 2015; 164:186-202.

22. Khan A, Gilani SS, Hussain F, Durrani MJ. Ethnobotany of Gokand Valley, District Buner, Pakistan. Pak J Biol Sci. 2003; 6(4):363- 369.

23. Ajaib M, Khan Z, Khan N, Wahab M. Ethnobotanical studies on useful shrubs of district Kotli, Azad Jammu \& Kashmir, Pakistan. Pak J Bot. 2010; 42(3):1407-1415.

24. Myers N, Muttermeier RA, Muttermeier CA, da Fonseca GAB, Kent J. Biodiversity hotspots for conservation priorities. Nature. 2000; 403:853-858.

25. Ved DK, Goraya GS. Demand and supply of medicinal plants in India. 2008.

26. Kala CP. Medicinal plants of the high-altitude cold desert in India: diversity, distribution and traditional uses. Int J Biodivers Sci Manag. 2006; 2(1): 43-56.

27. Fisher JF. Janet Rizvi. Trans-Himalayan Caravans: Merchant Princes and Peasant Traders in Ladakh. New York: Oxford University Press. 2003.

28. Khan SM, Page S, Ahmad H, Shaheen H, Ullah Z, Ahmad M, Harper DM. Medicinal flora and ethnoecological knowledge in the Naran Valley, Western Himalaya, Pakistan. J Ethnobiol Ethnomedicine. 2013; 9(1): 4.

29. Abbas Z, Khan SM, Alam J, Khan SW, Abbasi AM. Medicinal plants used by inhabitants of the Shigar Valley, Baltistan region of Karakorum Range-Pakistan. J Ethnobiol Ethnomedicine. 2017; 13(1):53.

30. Murthy KRK. A pictorial field guide-floral gallery of Himalayan Valley of Flowers and adjacent areas. Sudarshan Graphics Pvt. Ltd. Chennai (India), 2011.

31. Chaurasia OP, Khatoon N, Singh SB. Field guide plant biodiversity of Ladakh, WWF-India, 2008.

32. Klimeš L, Dickoré B. A contribution to the vascular plant flora of Lower Ladakh (Jammu \& Kashmir, India). Willdenowia. 2005; 35(1): 125-153. https://doi.org/10.3372/wi.35.35110 
33. Stewart RR. The flora of Ladak, Western Tibet. II. List of Ladak plants. Bull Torr Bot Club. 1916; 43(12): 625-650. https://www.jstor.org/stable/2479452

34. Sorensen T. A method of establishing groups of equal amplitude in plant sociology based on similarity of species content and its application to analyses of the vegetation on Danish commons, Videnski. Selskab. Biologiske. Skrifter. 1948; 5:1-34.

35. Dalirsefat SB, Da Silva Meyer A, Mirhoseini SZ. Comparison of similarity coefficients used for cluster analysis with amplified fragment length polymorphism markers in the silkworm Bombyxmori. J Insect Sci. 2009; 9:1-8.

36. Davis JC. Statistics and Data Analysis in Geology. John Wiley \& Sons. 1986.

37. Harper DAT(ed.). Numerical Palaeobiology. John Wiley \& Sons.

38. Gu Z, Gu L, Eils R, Schlesner M, Brors B. circlize implements and enhances circular visualization in R. Bioinformatics. 2014; 30:2811-2812.

39. Core Team R. a language and environment for statistical computing. R Foundation for Statistical Computing, Vienna, Austria. 2018. http://www.R-project.org.

40. Singh A. Lal M, Samant SS. Diversity, indigenous uses and conservation prioritization of medicinal plants in Lahaul valley, proposed Cold Desert Biosphere Reserve, India. Int J Biodivers Sci Manag. 2009; 5(3): 132-154.

41. Awan MR, lqbal Z, Shah SM, Jamal Z, Jan G, Afzal M, Majid A, Gul A. Studies on traditional knowledge of economically important plants of Kaghan Valley, Mansehra District, Pakistan. J Med Plant Res. 2011; 5(16): 3958-3967.

42. Ajaib M, Abid A, Ishtiaq M. Ethnobotanical studies of wild plant resources of Puna Hills, District Bhimber, AJK. Fuuast J Biol. 2016; 6(2):257-264.

43. Haider A, Qaiser M. The Enthnobotany of Chitral Valley,Pakistan with particular references to medicinal Plants. Pak J Bot, 2009; 41(4):2009-2041.

44. Kumar S, Sharma S. Species diversity, uses and distribution of medicinal plants along an altitudinal gradient in Paddar valley, Northwestern Himalaya. Int J Med Arom Plants. 2013; 3(3):343-351.

45. Muzafar I, Khuroo AA, Mehraj G, Hamid M, Rashid I, Malik AH. Floristic diversity along the roadsides of an urban biodiversity hotspot in Indian Himalaya. Plant Biosyst. 2019; 153(2):222-230.

46. Haq SM, Malik AH, Khuroo AA, Rashid I. Floristic composition and biological spectrum of Keran-a remote valley of northwestern Himalaya. Acta Ecol Sin. 2019; 39:372-379.

47. Gairola S, Sharma CM, Rana CS, Ghildiyal SK, Suyal S. Phytodiversity (Angiosperms and Gymnosperms) in Mandal-Choptaforest of Garhwal Himalaya, Uttarakhand, India. J Nat Sci. 2010; 8:1-17.

48. Rahman IU, Afzal AF, Iqbal ZA, ljaz F, Ali N, Asif M, Alam J, Majid A, Bussmann R W, Hart R. First insights into the floristic diversity, biological spectra and phenology of Manoor Valley, Pakistan. Pak J Bot. 2018; 50:1113-24. 
49. Begum S, Abd-Elslam NM, Adnan M, Tariq A, Yasmin A, Hameed R. Ethnomedicines of highly utilized plants in the temperate Himalayan region. Afr J Tradit Complement Altern Med. 2014; 11:132-142.

50. Ajaib M, Haider SK, Zikrea A, Siddiqui MF. Ethnobotanical Studies of Herbs of Agra Valley Parachinar, Upper Kurram Agency, Pakistan. Int J Biol Boitech. 2014; 11(1):71-83.

51. Jabbar A, Raza MA, Iqbal Z, Khan MN. An inventory of the ethnobotanicals used as anthelmintics in the southern Punjab (Pakistan). J ethnopharmacol, 2006; 108: 152-154. DOI: 1016/j.jep.2006.04.015

52. Malik ZA, Bhat JA, Bhatt AB. Forest resource use pattern in Kedarnath wildlife sanctuary and its fringe areas (a case study from Western Himalaya, India). En Pol. 2014;67: 138-145. https://doi.org/10.1016/j.enpol.2013.12.016

53. Sharma P, Patti P, Agnihotry A. Ethnobotanical and Ethnomedicinal uses of floristic diversity in Murari Devi and surrounding areas of Mandi district in Himachal Pradesh, India. Pak J Biol Sci. 2013; 16(10): 451-468.

54. Ahmed E, Arshad M, Saboor A, Qureshi R, Mustafa G, Sadiq S, Chaudhari SK. Ethnobotanical appraisal and medicinal use of plants in Patriata, New Murree, evidence from Pakistan. J Ethnobiol Ethnomed.2013; 9(1): 13. doi: 1186/1746-4269-9-13

55. Amjad MS, Arshad M, Qureshi R. Ethnobotanical inventory and folk uses of indigenous plants from Pir Nasoora National Park, Azad Jammu and Kashmir. Asian Pac J Trop Biomed, 2015; 5(3): 234241. https://doi.org/10.1016/S2221-1691(15)30011-3

56. Rana D, Bhatt A, Lal B. Ethnobotanical knowledge among the semi-pastoral Gujjar tribe in the high altitude (Adhwari's) of Churah subdivision, district Chamba, Western Himalaya. J Ethnobiol Ethnomed. 2019;15: https://doi.org/10.1186/s13002-019-0286-3

57. Kunwar RM, Fadiman M, Cameron M, Bussmann RW, Thapa-Magar KB, Rimal B, Sapkota P. Crosscultural comparison of plant use knowledge in Baitadi and Darchula districts, Nepal Himalaya. J Ethnobiol Ethnomed. 2018; 14(1):40. doi: 10.1186/s13002-018-0242-7.

58. Keter LK, Mutiso PC. Ethnobotanical studies of medicinal plants used by traditional health practitioners in the management of diabetes in lower eastern province, Kenya. J Ethnopharmacol. 2012; 139:74-80. https://doi.org/10.1016/j.jep.2011.10.014

59. Malik ZA, Bhat JA, Ballabha R, Bussmann RW, Bhatt AB. Ethnomedicinal plants traditionally used in health care practices by inhabitants of Western Himalaya. J Ethnopharmacol. 2015; 172:133-144. https://doi.org/10.1016/j.jep.2015.06.002

60. Rathore S, Tiwari JK, Malik ZA. Ethnomedicinal survey of herbaceous flora traditionally used in health care practices by inhabitants of Dhundsir gad watershed of Garhwal Himalaya, India. Global J Res Med PI Indig Med. 2015; 4 (4):65-78.

61. Singh S, Bhat JA, Malik ZA, Youssouf M, Bussmann RW, Kunwar RM. Sacred Groves in Western Himalaya, India: Community-Managed Nature Refuges for Conservation of Biodiversity and Culture. Ethnobot Res Appl. 2019;18: 1-21. http://dx.doi.org/10.17348/era.18.15.1-21

62. Akhtar N, Rashid A, Murad W, Bergmeier E. Diversity and use of ethnomedicinal plants in the region of Swat, North Pakistan. J Ethnobiol Ethnomed. 2013; 9:25. https://doi.org/10.1186/1746-4269-9-25 
63. Kunwar RM, Nepal BK, Kshhetri HB, Rai SK, Bussmann RW. Ethnomedicine in Himalaya: a case study from Dolpa, Humla, Jumla and Mustang districts of Nepal. J Ethnobiol Ethnomed. 2006; 2:27. DOI: 10.1186/1746-4269-2-27.

64. Ahmad M, Sultana S, Hadi SF, Hadda TB, Rashid S, Zafar M, Khan MA, Khan MPZ, Yaseen G. An ethnobotanical study of medicinal plants in high mountainous region of Chail valley (District SwatPakistan). J. Ethnobiol Ethnomedicine. 2014; 10: 36.

65. Srithi K, Balslev H, Wangpaka P, Srisanga P, Trisonthi C. Medicinal plant knowledge and its erosion among the Mien (Yao)in northern Thailand. J Ethnopharmacol. 2009;123(2):335-342.

66. Kala CP. Indigenous uses, population density, and conservation of threatened medicinal plants in protected areas of the Indian Himalayas. Conserv. Biol. 2005;19(2):368-78.

67. Kunwar RM, Pandey ML, Kunwar LM, Bhandari A. Medicinal Plants and Ethnomedicine in Peril: A Case Study from Nepal Himalaya. Evid Based Complement Alternat Med. 2014; 792789: 7 pages. https://doi.org/10.1155/2014/792789

68. Kala CP. Health traditions of Buddhist community and role of Amchis in trans-Himalayan region of India. Curr Sci. 2005;89(8):1331-1338.

69. Majaz AQ, Khurshid IM. Herbal medicine: a comprehensive review. Int J Pharm. 2016; 8(2):1-5.

70. Goraya GS, Ved DK. Medicinal plants in India: an assessment of their demand and supply. Dehradun: Ministry of AYUSH. 2017.

71. Dale VH, Joyce LA, McNulty S, Neilson RP, Ayres MP, Flannigan MD, Hanson PJ, Irland LC, Lugo AE, Peterson CJ, Simberloff D. Climate change and forest disturbances: climate change can affect forests by altering the frequency, intensity, duration, and timing of fire, drought, introduced species, insect and pathogen outbreaks, hurricanes, windstorms, ice storms, or landslides. 2001; 51(9):723734.

72. Brooks TM, Mittermeier RA, Mittermeier CG, Da Fonseca GA, Rylands AB, Konstant WR, Flick P, Pilgrim J, Oldfield S, Magin G, Hilton-Taylor C. Habitat loss and extinction in the hotspots of biodiversity. Conserv Biol. 2002; 16(4):909-923.

73. Ganie AH, Tali BA. Vanishing medicinal plants of Kashmir Himalaya. URL www. Greater Kashmir. com/news/gk-magazine/vanishing-medicinalplants-of-Kashmir-Himalaya/153598. html. 2013.

74. Vesk PA, Westoby M. Predicting plant species' responses to grazing. J Appl. Ecol. 2001;38(5):897909.

75. Tali BA, Ganie AH, Nawchoo IA, Wani AA, Reshi ZA. Assessment of threat status of selected endemic medicinal plants using IUCN regional guidelines: A case study from Kashmir Himalaya. J Nat Conserv. 2014; 23:80-89.

\section{Tables}

Table 1. List of plant species with their ethnobotanical usage in Ladakh 


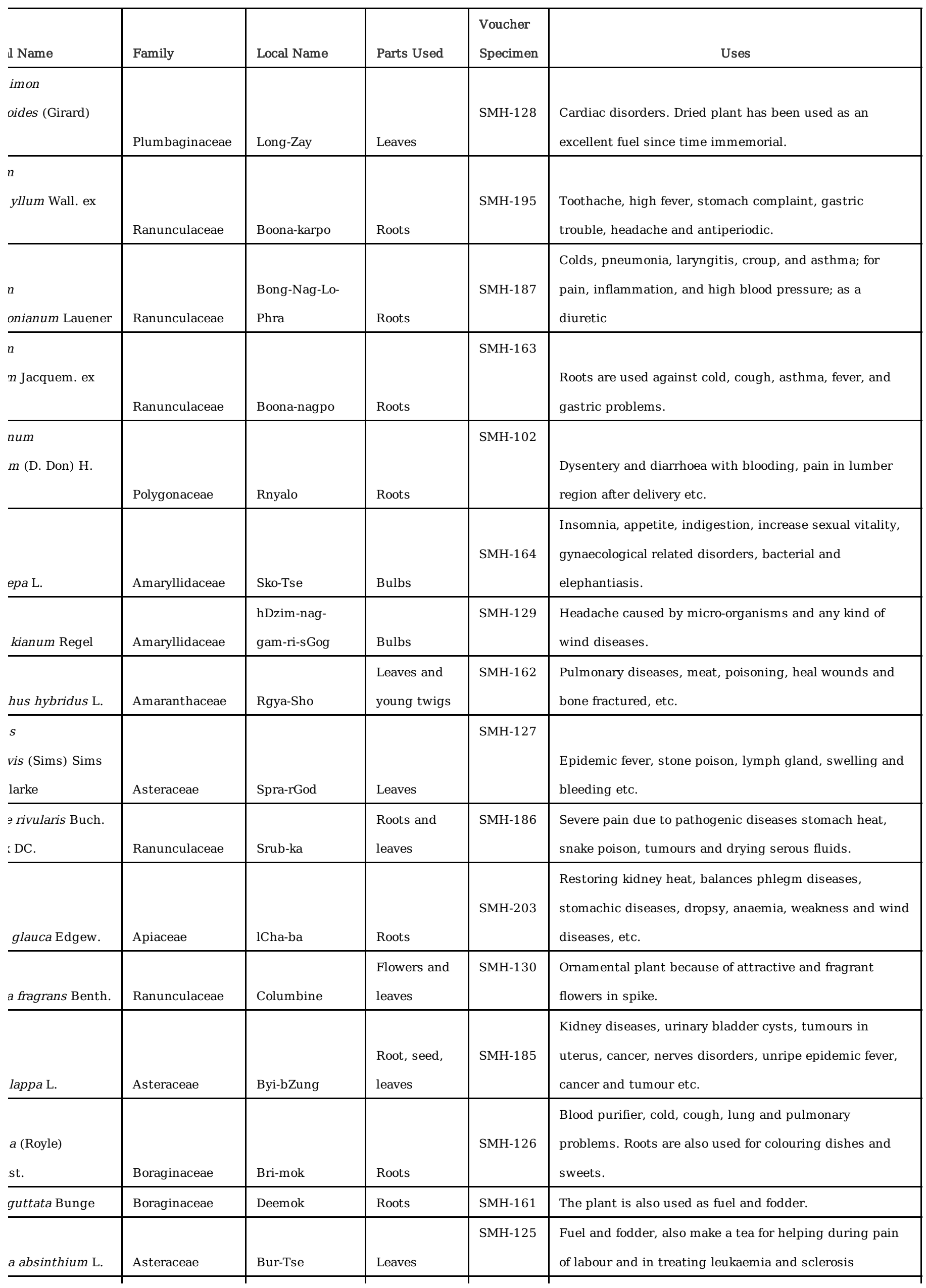




\begin{tabular}{|c|c|c|c|c|c|}
\hline a dracunculus L. & Asteraceae & $\begin{array}{l}\text { Tse-phat/tShar- } \\
\text { bong }\end{array}$ & Leaves & SMH-131 & $\begin{array}{l}\text { Pharyngitis, pulmonary diseases, swelling due to hot } \\
\text { disorders, etc. Used for digestive disorders, toothache }\end{array}$ \\
\hline ccidus Bunge & Asteraceae & $\begin{array}{l}\text { Me-Tok-Lug- } \\
\text { Mig/ Nia- } \\
\text { Mentok }\end{array}$ & Flowers & SMH-103 & $\begin{array}{l}\text { Poisoning, epidemic fever, infectious cold cough, spasms } \\
\text { of tendons and ligaments, drying pus and blood of } \\
\text { wounds, blisters, Ornamental. }\end{array}$ \\
\hline ylla Franch. & Berberidaceae & Sker-pa & Bark & SMH-124 & $\begin{array}{l}\text { Urinary frequency, diabetes, trachoma, and nephritis for } \\
\text { centuries in traditional medicinal system }\end{array}$ \\
\hline $\begin{array}{l}\text { ulicina Hook.f. } \\
\text { son }\end{array}$ & Berberidaceae & Khizer/Kiraring & $\begin{array}{l}\text { Roots and } \\
\text { stem }\end{array}$ & SMH-184 & Roots and bark are source of tonic \\
\hline z ciliata (Haw.) & Saxifragaceae & Pasanbheda & Whole plant & SMH-202 & For kidney stones \\
\hline spinosa L. & Capparaceae & Kabra & $\begin{array}{l}\text { Flowers and } \\
\text { fruits }\end{array}$ & SMH-160 & Flovour, food \\
\hline a brevifolia Kom. & Fabaceae & Brama & $\begin{array}{l}\text { Flowers, } \\
\text { fruits and } \\
\text { roots }\end{array}$ & SMH-132 & Inflammation of muscles and nerves. \\
\hline a tibetica Kom. & Fabaceae & mDzo-mo-shing & Roots & SMH-183 & $\begin{array}{l}\text { Blood disorders, skin diseases, heart disorders, eye } \\
\text { diseases, etc. }\end{array}$ \\
\hline$r$ Benth. & Fabaceae & Tama & Whole plant & SMH-159 & Fuel and fodder \\
\hline us lanatus L. & Asteraceae & Gur-gum & Flowers & SMH-123 & $\begin{array}{l}\text { Liver disorders, hepatitis, purify blood, anaemia, } \\
\text { strengthen bodily constituents, any kinds of fever } \\
\text { associated diseases and stop various kinds of bleeding, } \\
\text { etc. }\end{array}$ \\
\hline arvi L. & Apiaceae & Kos-Nyod & Fruit & SMH-104 & $\begin{array}{l}\text { Anthelminthic, carminative, stimulant, stomachic and } \\
\text { tonic. Seeds are used as condiment to add flavour for the } \\
\text { local dishes. }\end{array}$ \\
\hline (Benth.) Ali & Fabaceae & Byangbu/dama & $\begin{array}{l}\text { Roots and } \\
\text { fruits }\end{array}$ & SMH-182 & Antiseptic. The beans are eaten as vegetables. \\
\hline yllum Benth. & Fabaceae & Sari & Whole plant & SMH-196 & Fodder \\
\hline $\begin{array}{l}\text { montana Buch. } \\
\text { DC. }\end{array}$ & Ranunculaceae & $\begin{array}{l}\text { Dbye-Mong- } \\
\text { karpo }\end{array}$ & $\begin{array}{l}\text { Stem and } \\
\text { flowers }\end{array}$ & SMH-133 & Aerial parts are used to treat diabetes. \\
\hline tibetana Kuntze & Ranunculaceae & $\begin{array}{l}\text { dbi-mong/Sbi- } \\
\text { Cho }\end{array}$ & $\begin{array}{l}\text { Stem and } \\
\text { flowers }\end{array}$ & SMH-122 & $\begin{array}{l}\text { Wind or cold related tumours, wounds, arthritis, } \\
\text { pulmonary diseases, digestive heat, lack of appetite, } \\
\text { lymph fluid, etc. }\end{array}$ \\
\hline sis ovata Benth. & Campanulaceae & $\begin{array}{l}\text { Klup-Dud-Rdo- } \\
\text { Rje }\end{array}$ & $\begin{array}{l}\text { Leaves, } \\
\text { flowers and } \\
\text { fruits }\end{array}$ & SMH-181 & $\begin{array}{l}\text { Arthritis, gout, rheumatism, elephantiasis, leprosy, } \\
\text { nerves disorder, stiffening of ligaments and tendons, } \\
\text { joints pain, planetary diseases, evil spirits diseases }\end{array}$ \\
\hline $\begin{array}{l}\text { əpressa (D.Don) } \\
\text { in }\end{array}$ & Apiaceae & bam-po-mo-rig & $\begin{array}{l}\text { Bulbs and } \\
\text { Leaves }\end{array}$ & SMH-158 & Swelling limbs, internal tumour, muscular spasms, etc. \\
\hline s govaniana Wall. & Papaveraceae & Stong-Zil & $\begin{array}{l}\text { Roots and } \\
\text { leaves }\end{array}$ & SMH-134 & $\begin{array}{l}\text { Antipyretic, diuretic, to relieve gastric pain and muscular } \\
\text { pain, contagious fever, eye diseases and infections as well }\end{array}$ \\
\hline
\end{tabular}

Page 16/26 


\begin{tabular}{|c|c|c|c|c|c|}
\hline & & & & & as for treatment of swellings and burns. \\
\hline bipinnatus Cav. & Asteraceae & Pun-Da-Re-Ka & Roots & SMH-121 & Stops bleeding and treats blood fever. \\
\hline $\begin{array}{l}\text { hodium } \\
\text { ook.f.) Kitam. }\end{array}$ & Asteraceae & $\begin{array}{l}\text { Ming-Chan- } \\
\text { Nagpo }\end{array}$ & $\begin{array}{l}\text { Roots, flowers } \\
\text { and leaves }\end{array}$ & SMH-188 & $\begin{array}{l}\text { Severe diseases, severe swollen, larynx disorders, evil } \\
\text { spirits disorders, severe pain. }\end{array}$ \\
\hline $\begin{array}{l}\text { hiza } \\
\text { a (D.Don) Soó }\end{array}$ & Orchidaceae & Ambo-Lakpa & Roots & SMH-201 & $\begin{array}{l}\text { Energy boosters and help in improving health, and are } \\
\text { recommended for weak people. }\end{array}$ \\
\hline $\begin{array}{l}\text { asia } \\
\text { iiebold \& Zucc.) }\end{array}$ & Urticaceae & Ga -Dur & Fruits & SMH-197 & The fruits are edible and can be used to make wine. \\
\hline um & Ranunculaceae & Bya-rGod-sPos & $\begin{array}{l}\text { Stem and } \\
\text { leaves }\end{array}$ & SMH-105 & $\begin{array}{l}\text { Evil spirits diseases, poisoning, epidemic fever, itching, } \\
\text { cold cough, snake bite and blood infectious diseases }\end{array}$ \\
\hline ianum Royle & Ranunculaceae & Ba-ru-ra/Ladar & $\begin{array}{l}\text { Leaves, } \\
\text { flowers and } \\
\text { fruits }\end{array}$ & SMH-180 & Treating colic in Ladakh and also used as an insecticide. \\
\hline $\begin{array}{l}m \\
\text { C.B.Clarke ex }\end{array}$ & Asteraceae & Mentok-serpo & $\begin{array}{l}\text { Leaves and } \\
\text { flowers }\end{array}$ & SMH-120 & $\begin{array}{l}\text { Diphtheria, viral and bacterial diseases, upper back pain } \\
\text { due hypertension, swelling, etc. }\end{array}$ \\
\hline $\begin{array}{l}\text { shalum } \\
\text { yllum Benth. }\end{array}$ & Lamiaceae & Jib-rTse-Karpo & $\begin{array}{l}\text { Leaves and } \\
\text { flowers }\end{array}$ & SMH-179 & $\begin{array}{l}\text { Oral diseases and provide relieve from toothache, eye } \\
\text { diseases like irritation, burning sensation and pain. }\end{array}$ \\
\hline $\begin{array}{l}\text { shalum } \\
\text { um Maxim. }\end{array}$ & Lamiaceae & Pri-Yang-Ku & Leaves & SMH-200 & Hepatitis, gastritis, dizziness, arthritis and ulcer \\
\hline s cornigerus DC. & Asteraceae & Aczema & $\begin{array}{l}\text { Leaves and } \\
\text { roots }\end{array}$ & SMH-135 & $\begin{array}{l}\text { Septic wounds, tonic, cure yellowish colouration of eyes } \\
\text { (Jaundice). }\end{array}$ \\
\hline gerardiana Wall. & Ephedraceae & Tsepat & $\begin{array}{l}\text { Leaves, } \\
\text { stem, flowers } \\
\text { and fruits }\end{array}$ & SMH-119 & $\begin{array}{l}\text { Fever, hepatic diseases, rheumatism, bronchial asthma. } \\
\text { Toothbrush for the locals, fuel and fodder }\end{array}$ \\
\hline$m$ latifolium $\mathrm{L}$. & Onagraceae & $\begin{array}{l}\text { Byar-pan-chu- } \\
\text { tse }\end{array}$ & $\begin{array}{l}\text { Flowers, } \\
\text { leaves and } \\
\text { stem }\end{array}$ & SMH-106 & $\begin{array}{l}\text { Dropsy, against obstruction of urine, severe pain and } \\
\text { fever due to elephantiasis and arthritis diseases and } \\
\text { pimples, etc. }\end{array}$ \\
\hline eschkeana Vatke & Apiaceae & $\begin{array}{l}\text { Wild Hing/ tru- } \\
\text { nag }\end{array}$ & Roots & SMH-178 & Useful against septic wounds and cuts \\
\hline a verticillata & Liliaceae & Shri Khanta & Bulbs & SMH-189 & $\begin{array}{l}\text { The bulbs are antidote, antitussive, astringent, } \\
\text { expectorant and purgative }\end{array}$ \\
\hline z algida Pall. & Gentianaceae & $\begin{array}{l}\text { Tiktas/Spang- } \\
\text { gyan-karpo }\end{array}$ & Flowers & SMH-157 & $\begin{array}{l}\text { Inflammation of pharynx, bronchitis, cough, hoarseness } \\
\text { of throat, excess sputum, toxic and epidemic fevers. } \\
\text { Bitter taste with a cooling potency. }\end{array}$ \\
\hline z chirayita Roxb. & Gentianaceae & Tik-ta & Whole plant & SMH-118 & $\begin{array}{l}\text { Tonic, febrifuge, alterative, carminative, expectorant, } \\
\text { laxative, stomachic, anthelmintic and anti-diarrhoeal } \\
\text { properties. }\end{array}$ \\
\hline z urnula Harry & Gentianaceae & Ganga-chung & Whole plant & SMH-177 & $\begin{array}{l}\text { Laxative, stomachic, anthelmintic and anti-diarrhoeal } \\
\text { properties. }\end{array}$ \\
\hline $\begin{array}{l}m \\
s \text { Wall. ex DC. }\end{array}$ & Apiaceae & Spru-Nag & Roots & SMH-136 & $\begin{array}{l}\text { Effective in curing indigestion, sunburn, skin diseases } \\
\text { and external tumours }\end{array}$ \\
\hline
\end{tabular}




\begin{tabular}{|c|c|c|c|c|c|}
\hline is (L.) R.Br. & Orchidaceae & $\begin{array}{l}\text { Bye-lChe-Lag- } \\
\mathrm{Pa}\end{array}$ & Roots & SMH-198 & $\begin{array}{l}\text { Rejuvenating health, increase sperm and constituents of } \\
\text { the body, vital essence, aphrodisiac and improve kidney } \\
\text { heat, etc. }\end{array}$ \\
\hline $\begin{array}{l}\text { ae } \\
\text { des L. }\end{array}$ & Elaeagnaceae & $\begin{array}{l}\text { Tsermang/ } \\
\text { sTar-bu }\end{array}$ & Whole plant & SMH-156 & $\begin{array}{l}\text { Anti-ageing, anti-cold, memory restoration and energy } \\
\text { boosting properties, fodder and fuel value. }\end{array}$ \\
\hline 'emosa Hook.f. & Asteraceae & $\begin{array}{l}\text { Ma- } \\
\text { nu/pushkarmool }\end{array}$ & Roots & SMH-176 & $\begin{array}{l}\text { Bronchial asthma when half of the amount is mixed with } \\
\text { Kuth. Anthelmintic for children and antiseptic, } \\
\text { expectorant and diuretic. }\end{array}$ \\
\hline sa Pall. & Iridaceae & Dres-Ma & Whole plant & SMH-117 & $\begin{array}{l}\text { Heals wounds, appetite, stomach, small and large } \\
\text { intestinal cramps due to hot and cold, pathogenic cramps } \\
\text { and poisoning diseases, etc }\end{array}$ \\
\hline acilis (DC.) & Asteraceae & Rtga-Mkhris & Whole plant & SMH-190 & $\begin{array}{l}\text { Exhibited potent antihyperglycemic activity and } \\
\text { improved glucose tolerance; used as a remedy for } \\
\text { dysentery. }\end{array}$ \\
\hline s indica Bertol. & Cupressaceae & Shukpa & $\begin{array}{l}\text { Leaves and } \\
\text { bark }\end{array}$ & SMH-137 & $\begin{array}{l}\text { It used as incense by Buddhists, anti-inflammatory, } \\
\text { menstrual problem, inflammation of lung, liver, spleen, } \\
\text { kidney and gall bladder. }\end{array}$ \\
\hline $\begin{array}{l}\text { s recurva Buch. - } \\
\text { D.Don }\end{array}$ & Cupressaceae & $\begin{array}{l}\text { Shug-pa-tser- } \\
\text { chan }\end{array}$ & Leaves, fruits & SMH-155 & $\begin{array}{l}\text { Kidney, muscular spasms and fruits are one of the best } \\
\text { tonics. }\end{array}$ \\
\hline lolomiaea Boiss. & Asteraceae & $\begin{array}{l}\text { Bya-rog-nyungs- } \\
\text { ma }\end{array}$ & $\begin{array}{l}\text { Leaves and } \\
\text { bark }\end{array}$ & SMH-116 & Traditionally used as anti-rheumatic, antiseptic \\
\hline dissecta D. Don & Asteraceae & Khala & $\begin{array}{l}\text { Leaves and } \\
\text { stem }\end{array}$ & SMH-107 & $\begin{array}{l}\text { Paste is used to cures infections of female external } \\
\text { genital organ }\end{array}$ \\
\hline iana Rupr. & Plantaginaceae & Hong-len & Roots & SMH-175 & $\begin{array}{l}\text { Reduce inflammation, vital fever, liver fever, lungs fever, } \\
\text { intestinal fever, poisonous, painful cramps, muscular } \\
\text { spasms, child dysentery, etc. }\end{array}$ \\
\hline$s$ Houtt. & Lamiaceae & Zin-Tig & $\begin{array}{l}\text { Leaves and } \\
\text { stem }\end{array}$ & SMH-165 & $\begin{array}{l}\text { Regulating menstrual disturbance, dysmenorrhea, } \\
\text { amenorrhea, blood stasis, and postpartum haemorrhage, } \\
\text { diuretics. }\end{array}$ \\
\hline (Decne.) Jacq. ex & Caprifoliaceae & Phang-Ma & Flower & SMH-138 & Asthma, headache and gynaecological diseases etc. \\
\hline $\begin{array}{l}\text { sis } \\
\text { Royle }\end{array}$ & Papaveraceae & $\begin{array}{l}\text { Ud-Pal-Sngon- } \\
\text { Po }\end{array}$ & Leaves & SMH-154 & Traditionally used to cure headache \\
\hline ongifolia Wall. ex & Caprifoliaceae & sPyang-tsher & $\begin{array}{l}\text { Roots and } \\
\text { young twigs }\end{array}$ & SMH-191 & $\begin{array}{l}\text { It treats purgation phlegm disease, cancer, swelling and } \\
\text { indigestion, etc. }\end{array}$ \\
\hline a elegans Royle & Tamaricaceae & Hom-Bu & Stem & SMH-115 & $\begin{array}{l}\text { It treats various kinds of poisoning, fever of lungs, } \\
\text { diarrhoea, arthritis, uterine bleeding, stomach pain, } \\
\text { headache etc. }\end{array}$ \\
\hline a Desv. & Tamaricaceae & $\mathrm{Om}-\mathrm{Bu}$ & Stem & SMH-174 & Traditionally used for food poisoning \\
\hline loccosa Benth. & Lamiaceae & Shangukuram & $\begin{array}{l}\text { Leaves and } \\
\text { stem }\end{array}$ & SMH-153 & $\begin{array}{l}\text { The dried leaves and shoots are aromatic and used to add } \\
\text { flavour in local dishes. }\end{array}$ \\
\hline
\end{tabular}




\begin{tabular}{|c|c|c|c|c|c|}
\hline hookeri C.B. & Boraginaceae & Bri-Mog & $\begin{array}{l}\text { Roots, bark } \\
\text { and leaves }\end{array}$ & SMH-108 & $\begin{array}{l}\text { Used as remedy for asthma, cough, fever, gonorrhoea } \\
\text { leprosy, and phthisis }\end{array}$ \\
\hline $\begin{array}{l}s \\
\text { ylla (Pall.) DC. }\end{array}$ & Fabaceae & Tag-sha nagpo & Whole plant & SMH-139 & $\begin{array}{l}\text { The whole plant bears strong fragrance. The quantity of } \\
\text { aromatic oil is about } 0.01 \% \text {. }\end{array}$ \\
\hline $\begin{array}{l}\text { ris } \\
\text { a Rudolph }\end{array}$ & Orobanchaceae & Lug-Ru-Ser-Po & Flowers & SMH-166 & $\begin{array}{l}\text { A decoction of plant parts is used as diuretic, liver and } \\
\text { gall bladder, excessive seminal discharge and oedema. }\end{array}$ \\
\hline $\begin{array}{l}\text { ris } \\
\text { hifolia Schrenk }\end{array}$ & Orobanchaceae & $\begin{array}{l}\text { Lug-Ru-Smog- } \\
\text { PO }\end{array}$ & Stem & SMH-192 & Traditionally used to cure stomachache \\
\hline $\begin{array}{l}\text { laina } \\
\text { (Decne.) Miers }\end{array}$ & Solanaceae & $\begin{array}{l}\text { Lantang/Thang- } \\
\text { Phron-Nagpo }\end{array}$ & $\begin{array}{l}\text { Seeds and } \\
\text { leaves }\end{array}$ & SMH-109 & $\begin{array}{l}\text { Vermifuge and leaves are narcotic and used in treatment } \\
\text { of ulcer and eye diseases. }\end{array}$ \\
\hline eracioides Sibth. & Asteraceae & Rgya-Mkhur & Whole plant & SMH-152 & $\begin{array}{l}\text { It treats gastro-intestinal disorder, blood and bile } \\
\text { disorder, chronic fever, contagious fever and poisonous } \\
\text { fever, etc. }\end{array}$ \\
\hline a kurrooa Royle & Scrophulariaceae & $\begin{array}{l}\text { Hong-len / } \\
\text { Kutki }\end{array}$ & $\begin{array}{l}\text { Roots and } \\
\text { flowers }\end{array}$ & SMH-199 & $\begin{array}{l}\text { Roots used in asthmatic disorders, fever, blood } \\
\text { purification }\end{array}$ \\
\hline gum L. & Piperaceae & Pi-Pi-Ling & $\begin{array}{l}\text { Roots and } \\
\text { fruits }\end{array}$ & SMH-173 & Used for the prevention and treatment of prostate cancer. \\
\hline depressa Willd. & Plantaginaceae & Tha-Ram & $\begin{array}{l}\text { Leaves, } \\
\text { stem, flowers } \\
\text { and fruits }\end{array}$ & SMH-140 & $\begin{array}{l}\text { Dysentery, burned wounds, bleeding, inflammation } \\
\text { wounds and lymph fluids, etc. }\end{array}$ \\
\hline Im aviculare $\mathrm{L}$. & Polygonaceae & byi-na-sa & Whole plant & SMH-151 & $\begin{array}{l}\text { Obstruction of urine, burning sensation during urination, } \\
\text { jaundice, dermatological diseases with itching etc. }\end{array}$ \\
\hline a anserina $\mathrm{L}$. & Rosaceae & Gro-Lo Sa-hDzin & Leaves & $\mathrm{SMH}-144$ & Diarrhoea/dysentery and act as health tonic \\
\hline $\begin{array}{l}\text { lus } \\
\text { us Hand. -Mazz. }\end{array}$ & Ranunculaceae & $\begin{array}{l}\text { Ga-Tsah-am- } \\
\text { lChe-tsah }\end{array}$ & $\begin{array}{l}\text { Leaves and } \\
\text { flowers }\end{array}$ & SMH-110 & $\begin{array}{l}\text { Digestive heat, old wounds, dropsy, diphtheria and } \\
\text { tumours, etc. }\end{array}$ \\
\hline piciforme Royle & Polygonaceae & Lachhu & Roots & SMH-167 & $\begin{array}{l}\text { The purple coloured roots are used in the indigenous } \\
\text { system of medicine especially against rheumatism. }\end{array}$ \\
\hline um Royle & Polygonaceae & Chu-Rtsa & $\begin{array}{l}\text { Roots, stem } \\
\text { and leaves }\end{array}$ & SMH-150 & $\begin{array}{l}\text { Indigestion, abdominal diseases, boils, wounds and as an } \\
\text { astringent, gastritis, laxative. }\end{array}$ \\
\hline a Edgew. & Crassulaceae & $\begin{array}{l}\text { Shro-Lo/Cho- } \\
\text { Ngo-Ngo }\end{array}$ & Roots & SMH-143 & $\begin{array}{l}\text { Lung problems, cold, cough, fever, loss of energy and } \\
\text { pulmonary complaints, food }\end{array}$ \\
\hline $\begin{array}{l}\text { sacra (Prain ex } \\
\text { Iamet) S.H. Fu }\end{array}$ & Crassulaceae & Srolo-marpo & Roots & SMH-193 & $\begin{array}{l}\text { Tonic and it restores memory. The young leaves and } \\
\text { tender shoots are edible. 'Tantur', a delicious Ladakhi } \\
\text { dish. }\end{array}$ \\
\hline $\begin{array}{l}\text { ndron } \\
\text { yon D. Don }\end{array}$ & Ericaceae & Ba-Lu/Da-Lis & $\begin{array}{l}\text { Leaves and } \\
\text { flowers }\end{array}$ & SMH-111 & $\begin{array}{l}\text { High altitude diseases, chest pain, weakness, obstruction } \\
\text { of vocal cord, chronic bronchitis, stiffness limbs, phlegm } \\
\text { disorders and rejuvenated life. }\end{array}$ \\
\hline ientale Desf. & Grossulariaceae & $\begin{array}{l}\text { Askuta / se- } \\
\text { rgod }\end{array}$ & Fruit & SMH-141 & $\begin{array}{l}\text { Serous fluid diseases, swollen limbs. Fruits are used to } \\
\text { treats fever of poison, food poison, hepatitis, fever of gall } \\
\text { bladder, epidemic fever, etc. }\end{array}$ \\
\hline icea Wall. ex & Rosaceae & Shayh & Whole plant & SMH-149 & $\begin{array}{l}\text { The whole plant is used as ornamental hedge, also used } \\
\text { as fuel and fodder. }\end{array}$ \\
\hline bbiana Wall. ex & Rosaceae & Seba/Sia & Fruits & SMH-204 & Flowers are used for ornamental purposes, also used as \\
\hline
\end{tabular}




\begin{tabular}{|c|c|c|c|c|c|}
\hline & & & & & fuel and fodder. \\
\hline rdifolia L. & Rubiaceae & Btsod & $\begin{array}{l}\text { Stems and } \\
\text { roots }\end{array}$ & SMH-168 & $\begin{array}{l}\text { Blood disorders, blood fever, spreading fever, lungs fever, } \\
\text { kidney fever, intestine fever and stop bleeding. }\end{array}$ \\
\hline a Decne. & Asteraceae & Spang-rtsa & Flowers & SMH-148 & $\begin{array}{l}\text { Cure boils. The flowers also used for ornamental } \\
\text { purposes. }\end{array}$ \\
\hline əa lappa (Decne.) & Asteraceae & Kuth / Ru-ta & Roots & SMH-112 & Roots used against asthma and fever \\
\hline B.Clarke & Asteraceae & $\begin{array}{l}\text { Kon-pa-gab- } \\
\text { skyes-che-ba }\end{array}$ & Leaves & SMH-142 & $\begin{array}{l}\text { Chronic and fresh wounds, bleeding due to nerve } \\
\text { disorders, especially best for the mutton poisoning etc. }\end{array}$ \\
\hline wersii Ledeb. & Crassulaceae & Srolo-karpo & Whole plant & SMH-169 & $\begin{array}{l}\text { Provide cooling and soothing effect. This plant is given to } \\
\text { mulch cattle to increase milk production. }\end{array}$ \\
\hline tibetica Vatke & Lamiaceae & yakzas & Whole plant & SMH-145 & Fuel and fodder. \\
\hline entalis Trin. ex & Poaceae & Pilli/Makpen & Whole plant & SMH-172 & Fodder and fuel. \\
\hline hyllum (Kitam.) & Asteraceae & $\begin{array}{l}\text { mKhan-Chung- } \\
\text { Ser-mGo }\end{array}$ & $\begin{array}{l}\text { Leaves and } \\
\text { flowers }\end{array}$ & SMH-113 & $\begin{array}{l}\text { Bleeding like nose bleeding, swelling and inflammation of } \\
\text { the limbs, cancers, wounds, lungs disorders and renal } \\
\text { diseases, etc. }\end{array}$ \\
\hline Im & Asteraceae & Khamchu & $\begin{array}{l}\text { Leaves and } \\
\text { flowers }\end{array}$ & SMH-146 & $\begin{array}{l}\text { The dried leaves and flowers are fragrant and a good } \\
\text { source of essential oil. }\end{array}$ \\
\hline arvense L. & Brassicaceae & Bre-Ga & Leaves & SMH-170 & $\begin{array}{l}\text { Pulmonary diseases, various kinds of kidney diseases, } \\
\text { stop white discharges, dries up serous fluid in the limbs } \\
\text { of appetite etc. }\end{array}$ \\
\hline la emodi Benth. & Fabaceae & hBu-su-hang & $\begin{array}{l}\text { Seeds and } \\
\text { leaves }\end{array}$ & SMH-147 & $\begin{array}{l}\text { It heals sores, bone fracture, fever of lungs, fever } \\
\text { associated with poison and various kidney disorders, etc. }\end{array}$ \\
\hline ta Buch. -Ham. & Apocynaceae & Go-Snyod & Fruits & SMH-194 & $\begin{array}{l}\text { It cures dysentery, development of hot disorder of gall } \\
\text { bladder, etc. }\end{array}$ \\
\hline yperborea Jacq. & Urticaceae & Rza-Sot & Leaves & SMH-171 & $\begin{array}{l}\text { It promotes digestive and physical heat, cures wind } \\
\text { diseases associated with chronic fever. }\end{array}$ \\
\hline $\begin{array}{l}\text { mia } \\
\text { sa (Decne.) }\end{array}$ & Asteraceae & Palu & $\begin{array}{l}\text { Stem, young } \\
\text { twigs and } \\
\text { leaves }\end{array}$ & SMH-114 & $\begin{array}{l}\text { The whole plant is fragrant and considered as holy. It is } \\
\text { used for making dhoop that is used in house and } \\
\text { religious places. }\end{array}$ \\
\hline
\end{tabular}




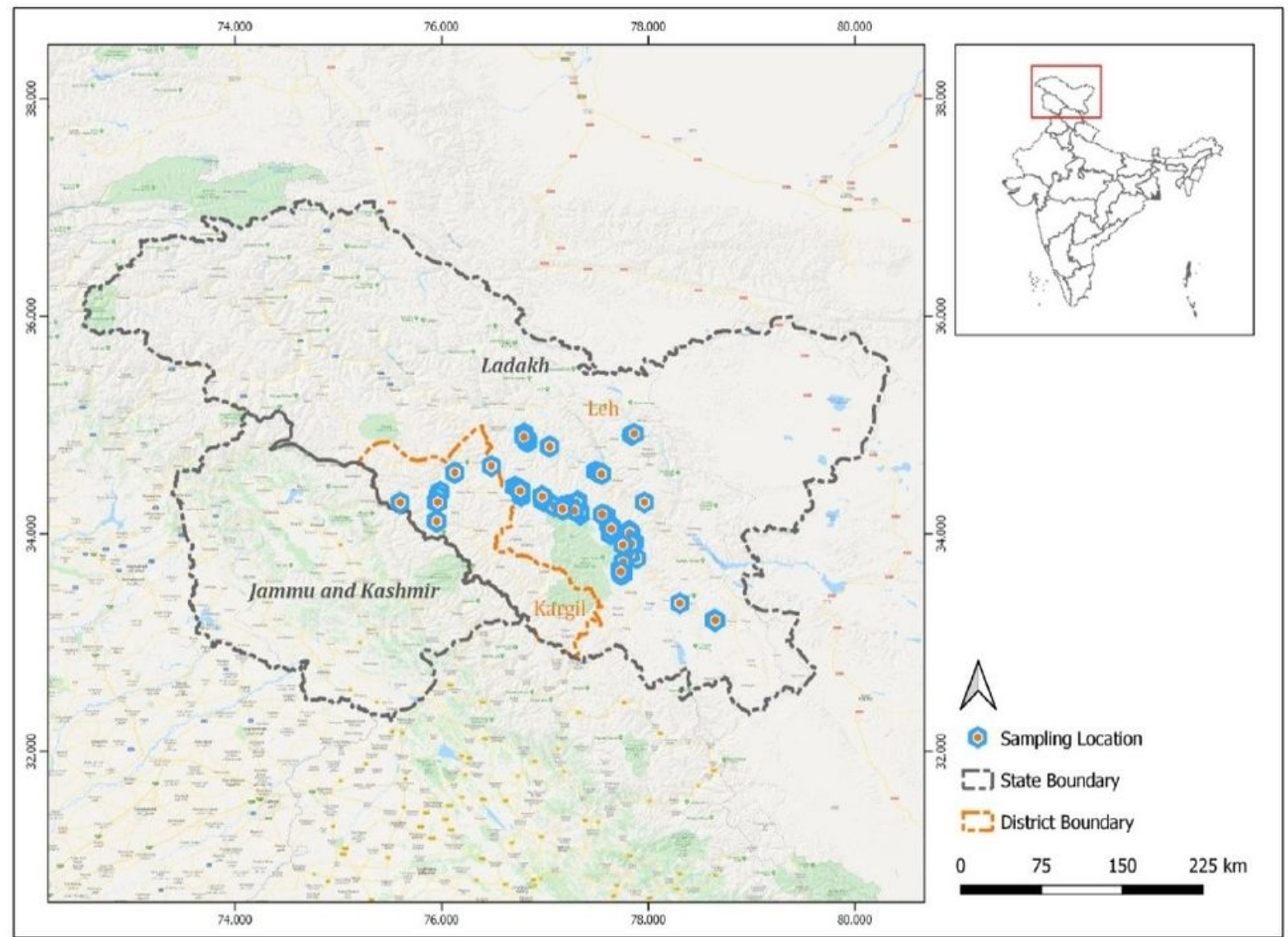

Figure 1

Map of study area 


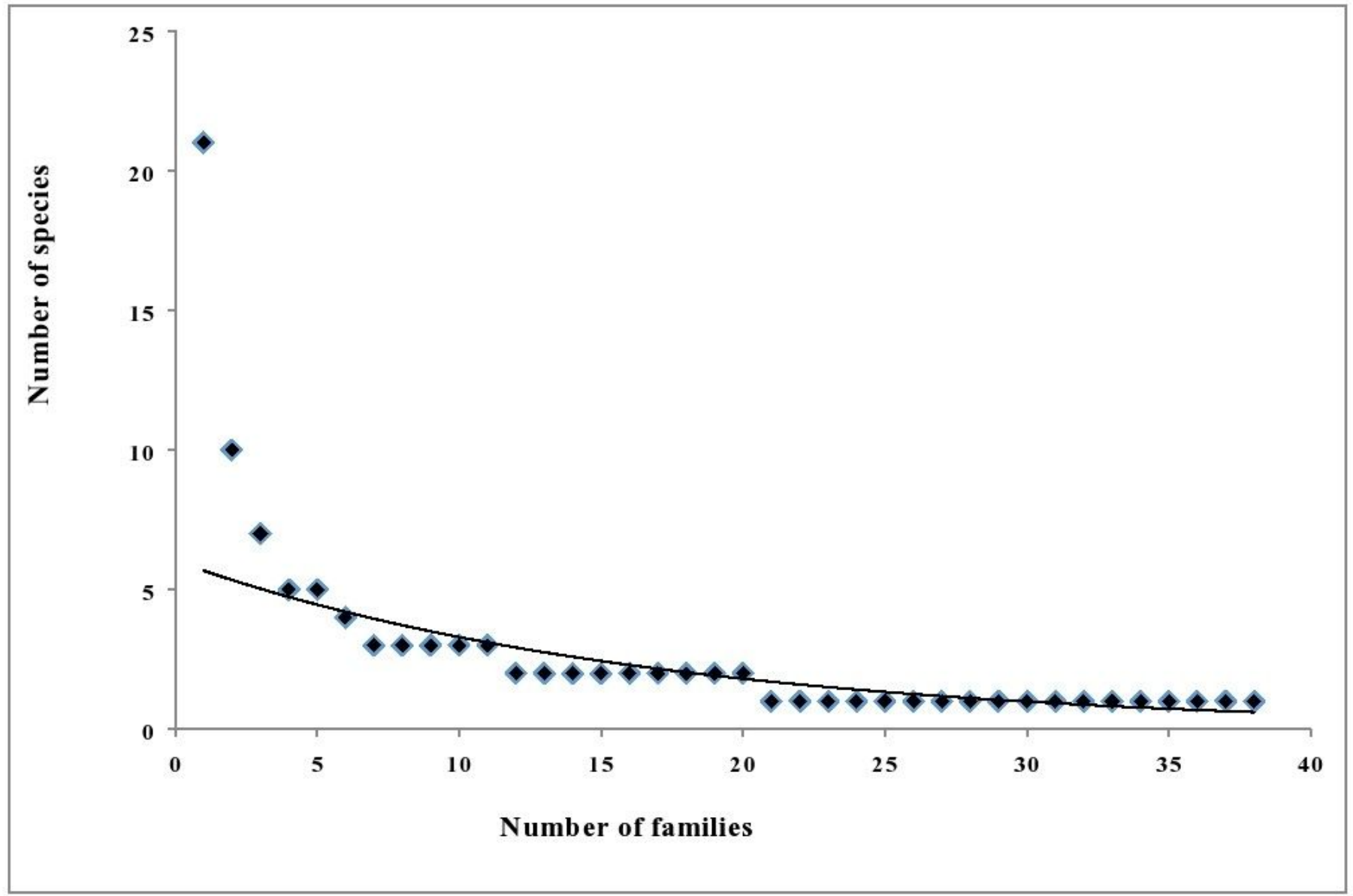

Figure 2

Distribution of Plant Species. The species dispersion across 38 families is unequal with six families contributed half of the species, while 32 families represented the remaining half of the species. 


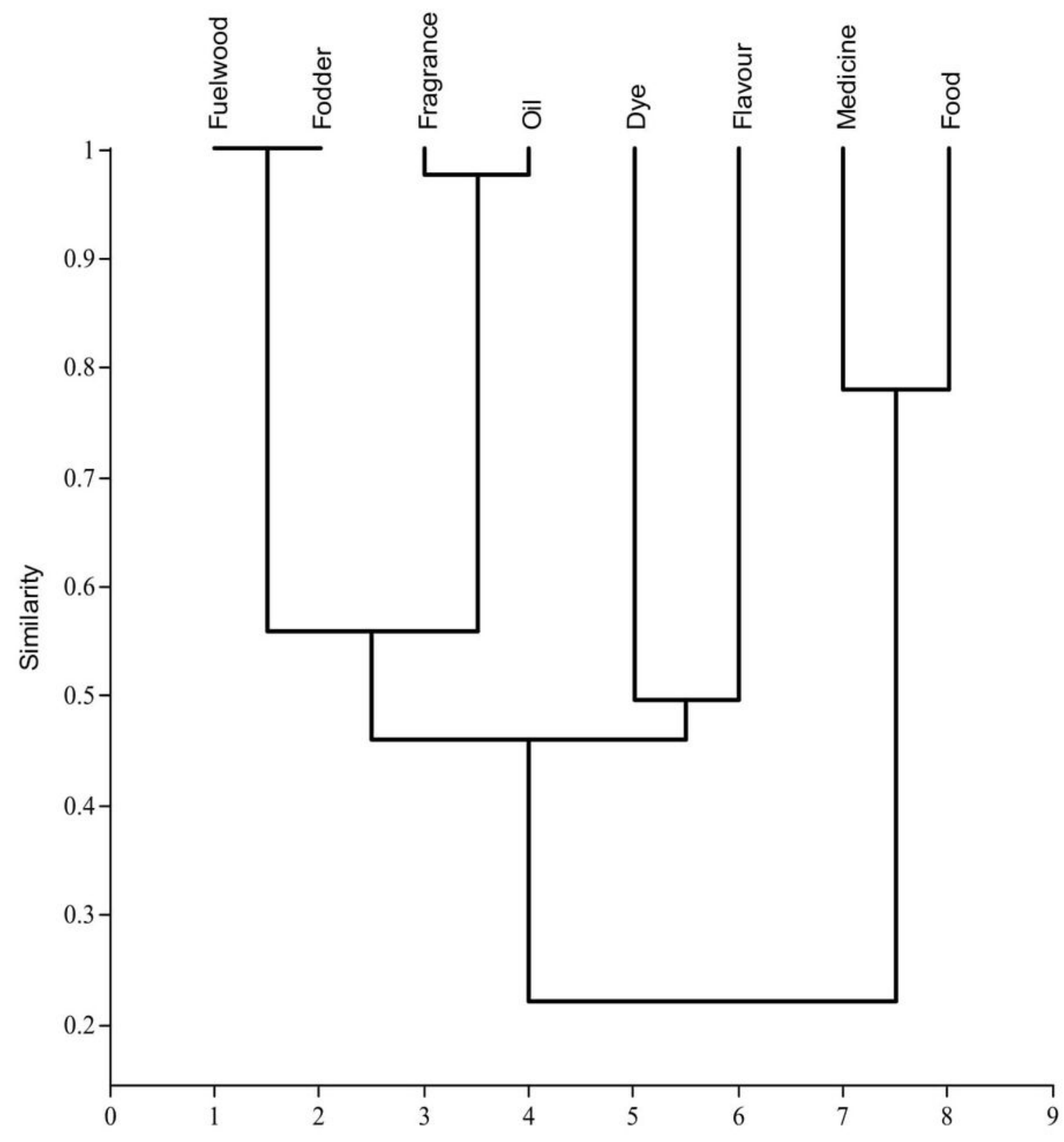

\section{Figure 3}

Plant Usage Classification. Three plant usage clusters were determined at a vertical maximum similarity of about 0.2 . The three distinctly separate clusters were: (1) food and medicinal plants; (2) dye and flavor; and (3) fragrance, oil, fuelwood and fodder. Clusters 2 and 3 showed almost $50 \%$ similarity in plant usage. The similarity in plant usage between fuelwood and fodder, and fragrance and oil, showed almost $100 \%$ of similarity. 


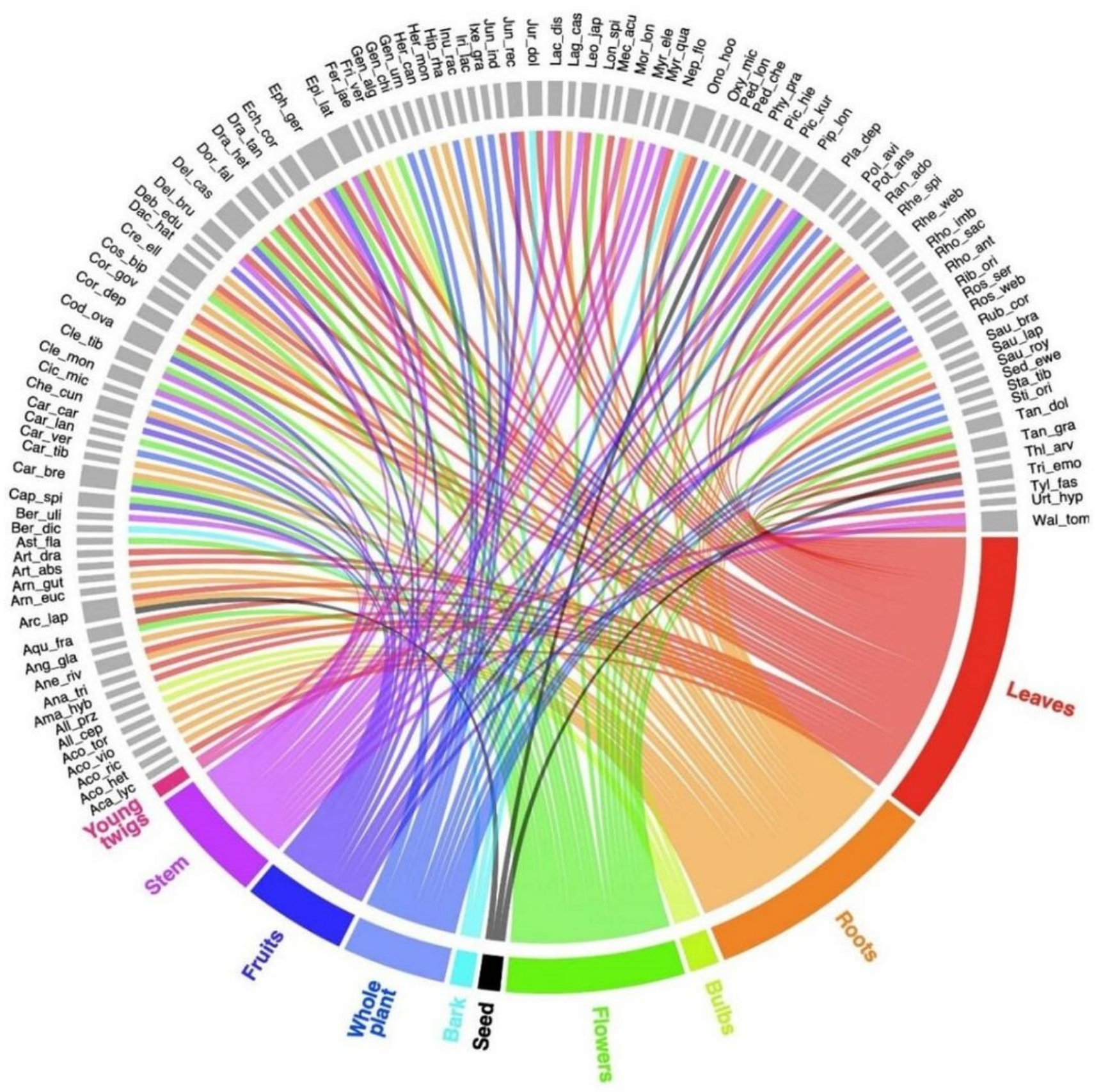

Figure 4

Plant parts used. Different parts of plants were documented for ethnobotanical usage with a significant difference between their usage $(\chi 2=100.12, d f=9, p<0.001)$. The most frequently used plant parts were leaves $(27 \%)$ followed by roots $(21 \%)$, flowers $(15 \%)$, stem ( $10 \%)$, fruits and whole plant ( $9 \%$ each), bulbs (3\%), bark and seed and young twigs ( $2 \%$ each) 


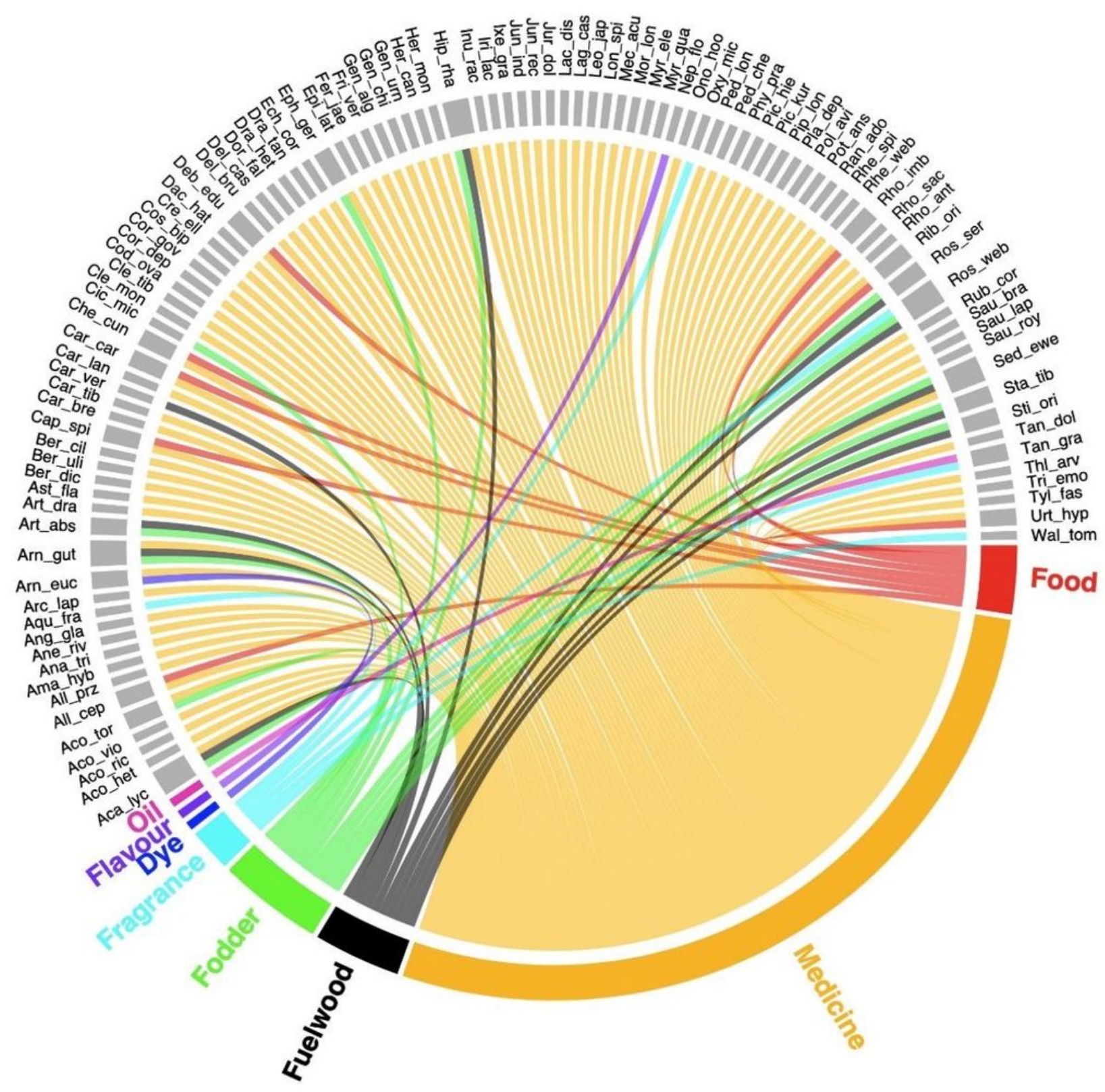

Figure 5

Preference analysis. The results of preference analysis showed a significant difference in plant usage $(x 2=408.56, d f=7, p<0.001)$. The highest priority of local people was for medicinal use of plant species (70\% responses) followed by fodder ( $9 \%$ ) and fuelwood ( $8 \%$ ), food (6\%), fragrance $(4 \%)$ and dye, flavor and oil (1\% each). 


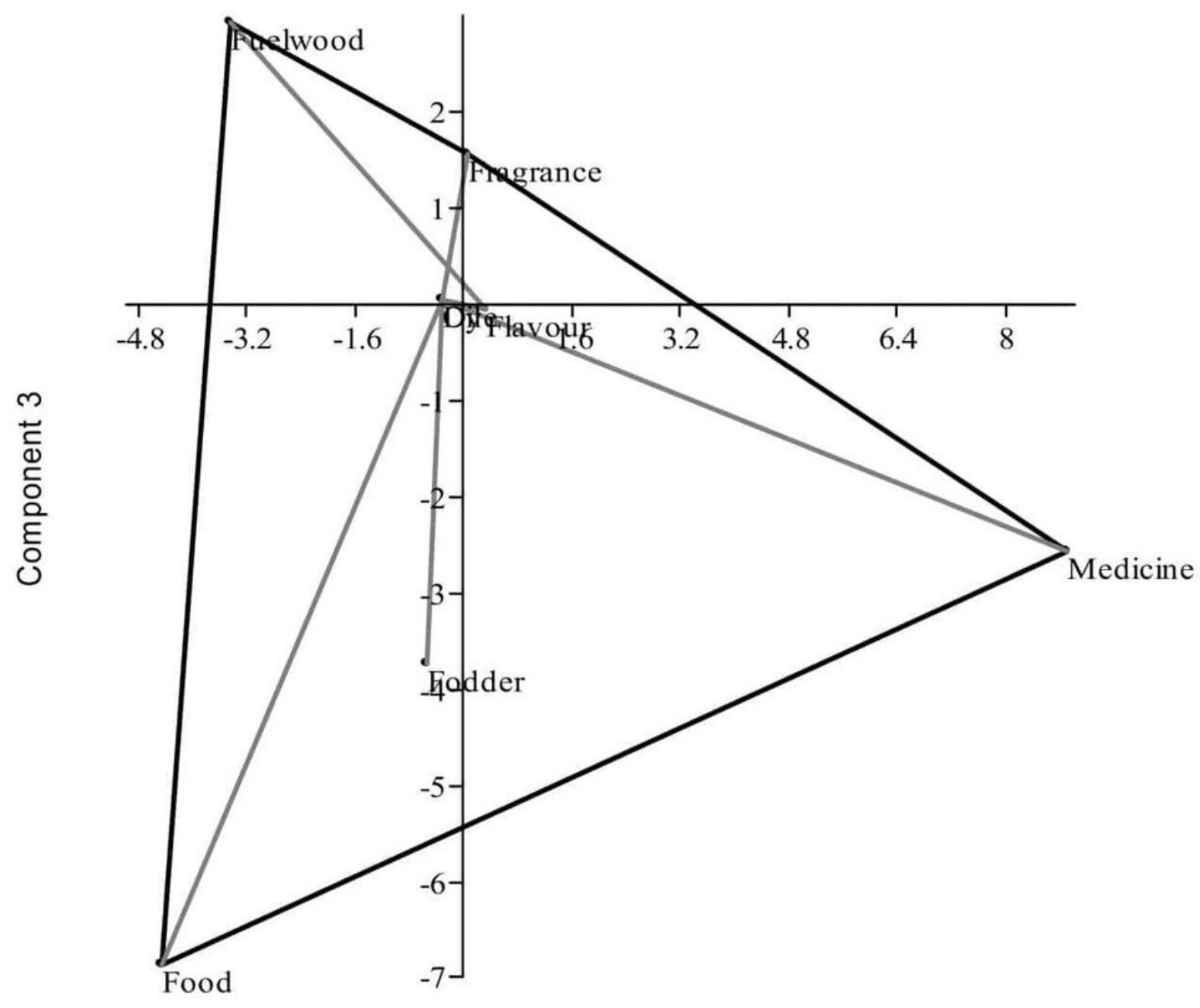

Component 1

\section{Figure 6}

The principal components analysis (PCA), showed distinct usage segregation based on variations in the preference levels. PCA correlated the most important components with other underlying variables. 